\title{
A Model of Certification Programs for Certified Translators and Interpreters
}

\author{
Yaghoob Javadi \\ Department of Language Teaching and Translation, Islamic Azad University, Varamin-Pishva Campus, Varamin, Iran \\ Tahereh Khezrab \\ Department of Language Teaching and Translation, Islamic Azad University, Varamin-Pishva Campus, Varamin, Iran
}

\begin{abstract}
The main part of a certification program is related to its exam, and it should be developed and assessed. For this purpose, two questions come to the mind: (1) Could the translators and interpreters accepted by the Certified Examination represent reasonable capabilities in doing certified translation and interpreting?; (2) What or Which type of test determines the best professional translators and interpreters possessing the best competence and skills? Finally, a variety of assessments can be followed to justify different kinds of testing systems or certification programs in order to design a general framework of a certification program.
\end{abstract}

Index Term - assessment, certification program, certified translators and interpreters, general framework

\section{INTRODUCTION}

The certification program introduces the procedure professional or certified translators and interpreters follow to obtain the certificate through authorised examination. This procedure is to be clarified, analyzed and assessed in this study.

To improve the skill in legal translation and interpreting, the best evaluation process will be performed by the exam. Therefore, two questions formulate in the researcher's mind: (1) Could the translators and interpreters accepted by the Certified Examination represent reasonable capabilities in doing certified translation and interpreting? (2) What or Which type of test determines the best professional translators and interpreters possessing the best competence and skills?

Through studying, the majority of articles were mostly focused on the certification programs in America, Canada, China and Australia introduced as the well-known and authorised centre of professional translation and interpreting practices although some other countries systems were also discussed. Finally, in terms of the analysis of different certification program, a comprehensive model or framework was presented.

\section{A. Certification Programs for Certified Translators and Interpreters}

1. Certification Program in the USA

For ATA exam, two passages should be translated from the three ones for which the result is formulated into pass or fail form. There are "two or more certification program graders" (Koby \& Baer, 2005, p. 33) in computerised forms whereas most of the handwritten ones are also be available. The "standard for passing" must be "near to a level 3" based on "Interagency Language Roundtable Scale" (ATA Website, 2019).

a. ATA Error Marking Scale

For "Standardised Error Marking" (SEM), "two primary documents" are considered "as the basis for all error marking" called: (1) Flowchart in "an Excel spreadsheet" adjusted for "length of texts" (Koby \& Baer, 2005, p. 33) (see Fig. 1 for Accreditation Forum, 2002, p. 57, as cited in Koby \& Baer, 2005, p. 39) for Error Point Decision, and (2) Framework for SEM. 


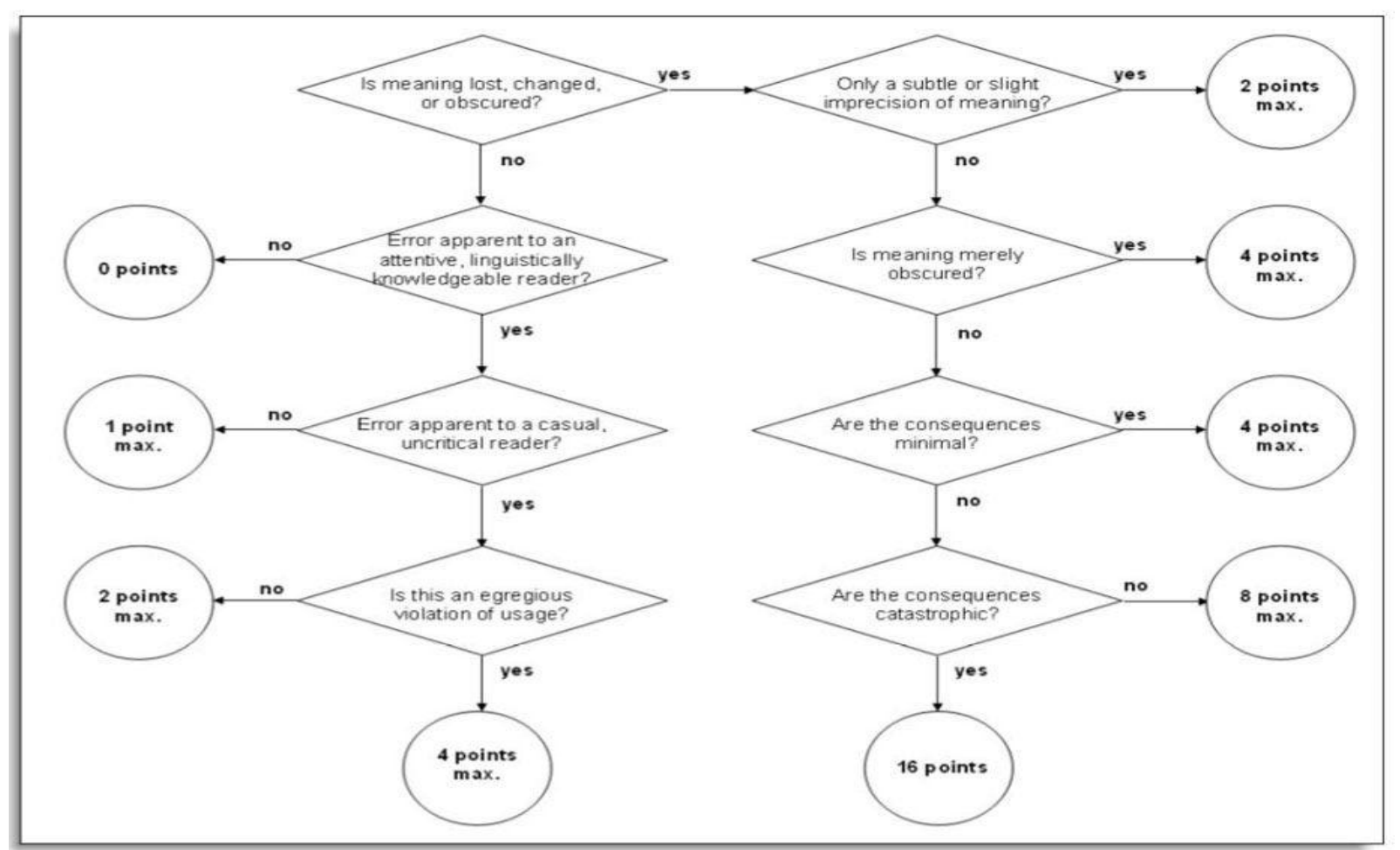

Figure 1. ATA assessment flowchart

As you see Fig. 2, ATA Error Marking Scale (Koby \& Baer, 2005b, p. 40) is an evaluation scale in order to make grade in the certification exam for "professional standards of error marking" in "translator training classroom" (Koby \& Baer, 2005b, p. 33).

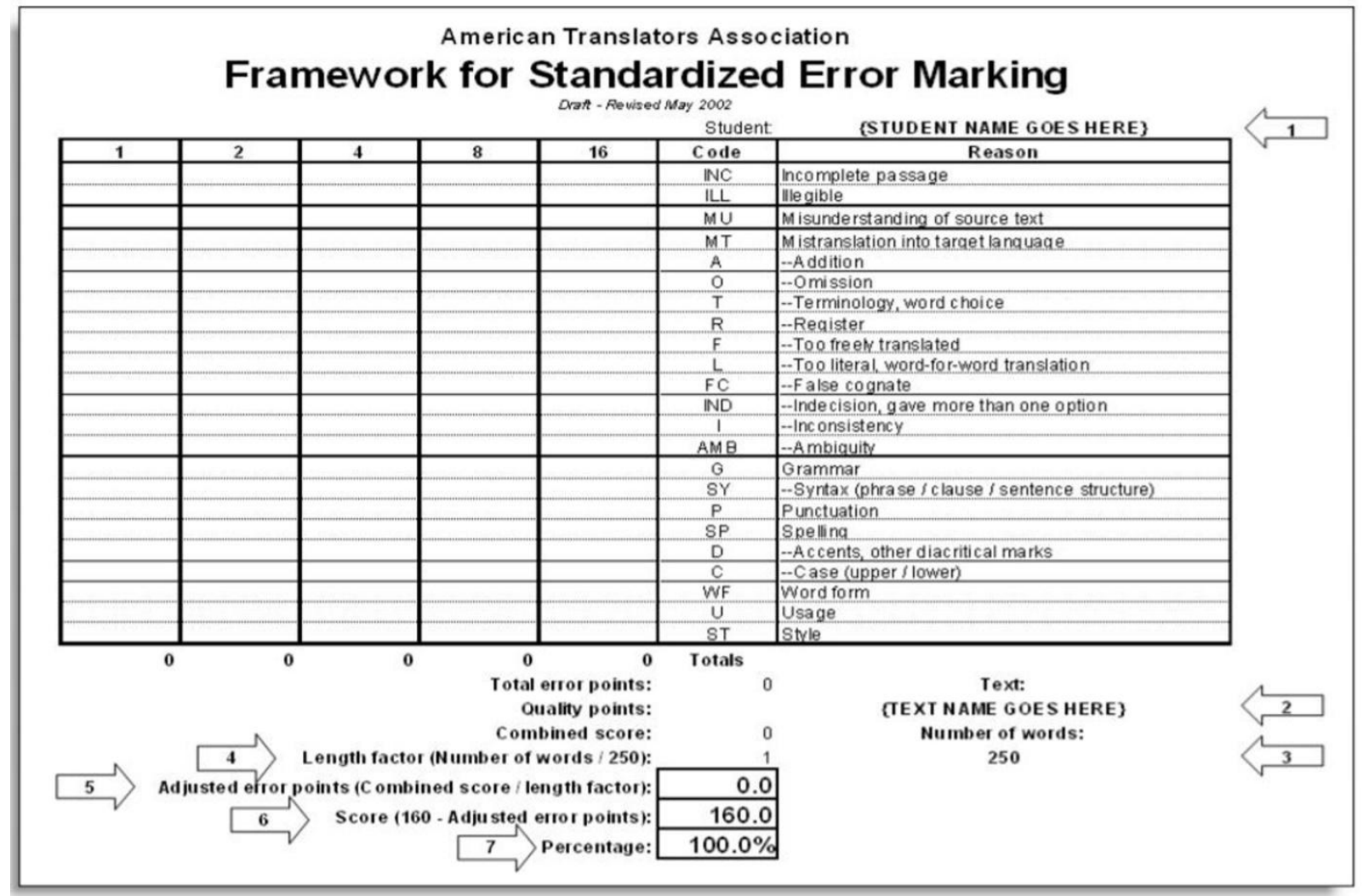

Figure 2. Excel spreadsheet

Therefore, in terms of factors such as "turning an ATA score into a grade, length, and difficulty" for the purpose of transforming "a product-oriented scale into a more process-oriented" scale, the ATA error marking scale is adapted and adjusted (Koby \& Baer, 2005b, p. 43). 
b. Applying Translation Quality Standards

For "Language Service Providers (LSPs)" (Hall, 2011, pp. ii, Hall-2), Translation Quality Standards classify into (Hall, 2011, p. Hall-iii):

(a) "Provider-Oriented Translation Quality Standards": They entail the "language competency" of the source and target language, translation competency and subject-matter competency based on a certification issued "by a professional organisation, government body, or academic institution" (Stejskal, 2006, p. 12, as cited in Hall, 2011 , p. Hall-6).

(b) "Product-Oriented Translation Quality Standards": They pay attention to the quality of translation product to assess a statistic for "the number of errors" in each text (Stejskal, 2006, p. 12). Examples of such standards are introduced as "the Translation Quality Metric" from "the Society of Automotive Engineering (SAE J2450), the Localisation Industry Standards Association (LISA) QA Model," and also "the Translation Quality Index" from "Riccardo Schiaffino and Franco Zearo" (Hall, 2011, p. Hall-7).

(c) "Process-Oriented Translation Quality Standards": This process contains "defining project specifications, terminology management, translation, editing, formatting, proofreading, quality control, and post project review, making them the most appropriate standards for assessing LSPs" (ATA, 2008, p. 30). Examples of such standards are introduced as "international standard ISO 9001, EU standard EN 15038: 2006, U.S. standard ASTM F 2575-06, Canadian standard CAN/CGSB-131.10-2008, Italian standard UNI 10574, German standard DIN 2345, Austrian standards ÖNORM D1200 and D1201, and Chinese standard GB/T 19363.1" (Hall, 2011, p. Hall-9).

c. Job Task Analysis (JTA) and Validity of Translator Certification Examinations

ATA Job Task Analysis (JTA) as the "translator competence" was performed to clarify a "professional translator" based on "13 knowledge areas, 13 skills and 10 abilities (KSAs)" (Koby \& Melby, 2013, pp. 174, 184-186). To compare ATA results with "a recent European Project" called the Commissie Kwaliteitseisen Tolken en Vartalers (2005, p. 3) (Koby \& Melby 2013, pp. 174, 187), the quality and integrity of the certification program were represented by the "validity, reliability and other aspects of ISO 17024" (Koby \& Melby, 2013, p. 207).

Kaur and Singh (2005) followed their survey by "fifty-five experienced Malaysian part-time translators of scientific texts from English to Malay" on a questionnaire of "the characteristics of an effective translator" (Koby \& Melby, 2013, pp. 188-189):

(a) Being proficient in both languages and in translation to the "mother tongue"

(b) Knowing both cultures and skopos of the task

(c) Having tools: "dictionaries, thesauri, terminology, computer, printer, etc."

(d) Being an specialist for a "subject-matter content" in communication

(e) Knowing translation as a "direct and indirect language-learning activity"

(f) Being a "committed and disciplined team worker"

(g) Being acquainted with "basic translation theory and practice"

Cao (1996, p. 328, as cited in Koby \& Melby, 2013, p. 190) divided "translation proficiency" with regard to the framework pointed out by Bachman (1991) in the following way (Koby \& Melby, 2013, p. 191):

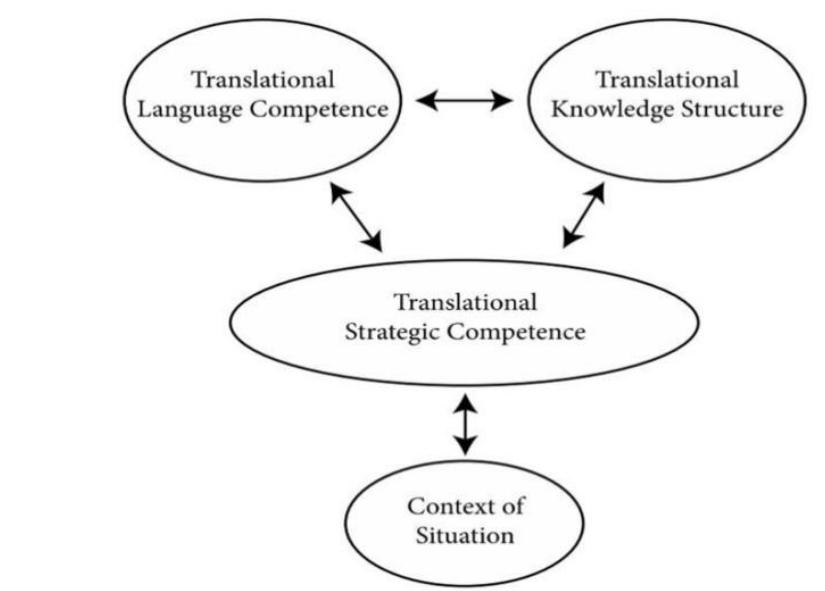

Figure 3. Components of translation proficiency adapted from Bachman (1991)

Hatim and Mason (1997, p. 205) designed a table for translation skills as follows in Table I (Koby \& Melby, 2013, p. 192). 
TABLE I.

TRANSLATION SKILLS

\begin{tabular}{|l|l|l|}
\hline source text & & target text \\
\hline $\begin{array}{l}\text { PROCESSING } \\
\text { SKILLS }\end{array}$ & TRANSFER SKILLS & $\begin{array}{l}\text { PROCESSING } \\
\text { SKILLS }\end{array}$ \\
\hline $\begin{array}{l}\text { Recognizing } \\
\text { intertextuality } \\
\text { (genre/discourse/text) }\end{array}$ & $\begin{array}{l}\text { Strategic re- } \\
\text { negotiation by } \\
\text { adjusting: }\end{array}$ & $\begin{array}{l}\text { Establishing } \\
\text { intertextuality } \\
\text { (genre/discourse/text) }\end{array}$ \\
\cline { 1 - 2 } $\begin{array}{l}\text { Locating situationality } \\
\text { (register, etc.) }\end{array}$ & $\begin{array}{l}\text { effectiveness } \\
\text { efficiency } \\
\text { relevance }\end{array}$ & $\begin{array}{l}\text { Establishing } \\
\text { situationality (register, } \\
\text { etc.) }\end{array}$ \\
\cline { 1 - 2 } $\begin{array}{l}\text { Inferring intentionality } \\
\text { Organizing texture } \\
\text { lex. choice, synt. } \\
\text { arrangement, cohesion) } \\
\text { and structure }\end{array}$ & $\begin{array}{l}\text { to: } \\
\text { task (brief, initiator, } \\
\text { etc.) }\end{array}$ & $\begin{array}{l}\text { Ouganizing texture } \\
\text { (lex. choice, synt. } \\
\text { arrangement, cohesion) } \\
\text { and structure }\end{array}$ \\
\cline { 1 - 2 } $\begin{array}{l}\text { Judging informativity } \\
\text { (static/dynamic) } \\
\text { in terms of estimated } \\
\text { impact on: } \\
\text { source text readership }\end{array}$ & $\begin{array}{l}\text { in fulfillment of a: } \\
\text { rhetorical purpose } \\
\text { (plan, goal) }\end{array}$ & $\begin{array}{l}\text { Balancing } \\
\text { informativity } \\
\text { (static/dynamic) } \\
\text { in terms of estimated } \\
\text { impact on: } \\
\text { target text readership }\end{array}$ \\
\hline
\end{tabular}

PACTE (2000, p. 101) group performed a project in the translation competence (Koby \& Melby, 2013, p. 193). While Neubert (2000) pointed out "translation competence" in five categories "language, textual, subject area, cultural, and transfer competence" for "translation", "the complex cultural task" is viewed as another competency for "professional translation" (Koby \& Melby, 2013, p. 196). A comparison demonstrated for "three translation subcompetence approaches"as in Table II (Koby \& Melby, 2013, p. 197).

TABLE II

A COMPARISON OF THREE TRANSLATION SUBCOMPETENCE APPROACHES

\begin{tabular}{|c|c|c|}
\hline Neubert (2000) & PACTE (2000-2008) & Kelly (2005) \\
\hline $\begin{array}{l}\text { - language } \\
\text { competence } \\
\text { - textual competence }\end{array}$ & - bilingual subcompetence & $\begin{array}{l}\text { - communicative and } \\
\text { textual competence }\end{array}$ \\
\hline $\begin{array}{l}\text { - subject [area] } \\
\text { competence }\end{array}$ & $\begin{array}{l}\text { - extra-linguistic } \\
\text { subcompetence }\end{array}$ & $\begin{array}{l}\text { - subject area } \\
\text { competence }\end{array}$ \\
\hline $\begin{array}{l}\text { - cultural } \\
\text { competence }\end{array}$ & $\begin{array}{l}\text { - extra-linguistic } \\
\text { subcompetence }\end{array}$ & $\begin{array}{l}\text { - cultural and } \\
\text { intercultural } \\
\text { competence }\end{array}$ \\
\hline $\begin{array}{l}\text { - transfer } \\
\text { competence }\end{array}$ & $\begin{array}{l}\text { - knowledge-about- } \\
\text { translation subcompetence } \\
\text { - instrumental } \\
\text { subcompetence }\end{array}$ & $\begin{array}{l}\text { - professional and } \\
\text { instrumental } \\
\text { competence }\end{array}$ \\
\hline $\begin{array}{l}\text { transfer } \\
\text { competence }\end{array}$ & $\begin{array}{l}\text { - strategic } \\
\text { sub[super]competence }\end{array}$ & $\begin{array}{l}\text { - strategic } \\
\text { competence }\end{array}$ \\
\hline N/A & $\begin{array}{l}\text { psycho-physiological } \\
\text { components }\end{array}$ & $\begin{array}{l}\text { - psycho- } \\
\text { physiological or } \\
\text { attitudinal } \\
\text { competence }\end{array}$ \\
\hline N/A & N/A & $\begin{array}{l}\text { - interpersonal } \\
\text { competence }\end{array}$ \\
\hline
\end{tabular}

In fact, EMT Expert Group (2009) developed the framework of "European Masters in Translation Program" for training translation from "knowledge, skills and abilities" into 49 competencies under the following six headings (Koby \& Melby, 2013, p. 197):

(a) Language Competence

(b) Intercultural Competence (with subheadings of Sociolinguistic Competence and Textual Competence)

(c) Information Mining Competence

(d) Technological Competence, Thematic Competence

(e) Translation Service Provision Competence (with subheadings of the Interpersonal Dimension and Production Competence) 
In Table III, a comparison is made between the categories of Neubert, PACTE, Kelly, and EMT, "using EMT as a model and rearranging the others", and there is a difference between the EMT model and older models in which the EMT possess some "additional categories" (Koby \& Melby, 2013, p. 199).

TABLE III

COMPARISON OF CATEgories In The LiTERATURE AdAPTED From KoBy \& MELBy (2013, P. 199)

\begin{tabular}{|c|c|c|c|c|}
\hline \multicolumn{2}{|c|}{$\begin{array}{l}\text { European Masters in } \\
\text { Translation (2009) }\end{array}$} & $\begin{array}{l}\text { Neubert } \\
(2000)\end{array}$ & PACTE (2000-2008) & Kelly (2005) \\
\hline \multicolumn{2}{|c|}{ Language Competence } & $\begin{array}{l}\text { language } \\
\text { competence }\end{array}$ & $\begin{array}{l}\text { bilingual } \\
\text { subcompetence }\end{array}$ & $\begin{array}{l}\text { communicative } \\
\text { and textual } \\
\text { competence }\end{array}$ \\
\hline \multirow[t]{2}{*}{$\begin{array}{l}\text { Intercultural } \\
\text { Competence }\end{array}$} & $\begin{array}{l}\text { Sociolinguistic } \\
\text { Competence }\end{array}$ & $\begin{array}{l}\text { cultural } \\
\text { competence }\end{array}$ & & \multirow{2}{*}{$\begin{array}{l}\text { cultural and } \\
\text { intercultural } \\
\text { competence }\end{array}$} \\
\hline & $\begin{array}{l}\text { Textual } \\
\text { Competence }\end{array}$ & $\begin{array}{l}\text { textual } \\
\text { competence }\end{array}$ & $\begin{array}{l}\text { extra-linguistic } \\
\text { subcompetence }\end{array}$ & \\
\hline \multicolumn{5}{|c|}{$\begin{array}{l}\text { Information Mining } \\
\text { Competence }\end{array}$} \\
\hline \multicolumn{2}{|c|}{ Technological Competence } & & $\begin{array}{l}\text { instrumental } \\
\text { subcompetence }\end{array}$ & $\begin{array}{l}\text { professional } \\
\text { and } \\
\text { instrumental } \\
\text { competence }\end{array}$ \\
\hline \multicolumn{2}{|c|}{ Thematic Competence } & & $\begin{array}{l}\text { extra-linguistic } \\
\text { subcompetence }\end{array}$ & $\begin{array}{l}\text { subject area } \\
\text { competence }\end{array}$ \\
\hline \multirow[t]{2}{*}{$\begin{array}{l}\text { Translation } \\
\text { Service } \\
\text { Provision } \\
\text { Competence }\end{array}$} & $\begin{array}{l}\text { Interpersonal } \\
\text { Dimension }\end{array}$ & & $\begin{array}{l}\text { psycho-physiological } \\
\text { components }\end{array}$ & $\begin{array}{l}\text { psycho- } \\
\text { physiological } \\
\text { or attitudinal } \\
\text { competence } \\
\text { interpersonal } \\
\text { competence }\end{array}$ \\
\hline & $\begin{array}{l}\text { Production } \\
\text { Competence }\end{array}$ & $\begin{array}{l}\text { transfer } \\
\text { competence }\end{array}$ & $\begin{array}{l}\begin{array}{l}\text { knowledge-about- } \\
\text { translation } \\
\text { subcompetence }\end{array} \\
\text { instrumental } \\
\text { subcompetence } \\
\text { strategic } \\
\text { sub[super]competence }\end{array}$ & $\begin{array}{l}\text { professional } \\
\text { and } \\
\text { instrumental } \\
\text { competence. } \\
\text { strategic } \\
\text { competence }\end{array}$ \\
\hline
\end{tabular}

Table IV (Koby \& Melby, 2013, p. 200) makes a comparison of "the EMT model" and "the ATA focus groups". It is worth mentioning to note that a comprehensive comparison between EMT and ATA can be accessible in http://www.ttt.org/trans-int/competence.htm (Koby \& Melby, 2013, p. 200).

TABLE IV.

COMPARISON OF MAJOR EMT AND ATA FOCUS GROUP CATEGORIES

\begin{tabular}{|l|l|l|}
\hline \multicolumn{2}{|l|}{ European Masters in Translation (2009) } & ATA Focus Groups \\
\hline Language Competence & Language Pair Knowledge Areas \\
\hline $\begin{array}{l}\text { Intercultural } \\
\text { Competence }\end{array}$ & Sociolinguistic Competence & Translation Skills \\
\cline { 2 - 3 } & Textual Competence & Translation Skills \\
\hline \multirow{2}{*}{ Information Mining Competence } & $\begin{array}{l}\text { Translation Skills } \\
\text { Other Skills }\end{array}$ \\
\hline Technological Competence & Other Skills \\
\hline Thematic Competence & Other Knowledge Areas \\
\hline \multirow{2}{*}{$\begin{array}{l}\text { Translation } \\
\text { Service } \\
\text { Provision } \\
\text { Competence }\end{array}$} & Production Competence & $\begin{array}{l}\text { Other Knowledge Areas } \\
\text { Other Skills }\end{array}$ \\
\cline { 2 - 3 } & & $\begin{array}{l}\text { Translation Skills } \\
\text { Other Abition Abilities }\end{array}$ \\
\hline $\begin{array}{l}\text { Onot part of } \\
\text { model) }\end{array}$ & & $\begin{array}{l}\text { Education and Training } \\
\text { Non-Degree Education and Training } \\
\text { Professional Association }\end{array}$ \\
\hline
\end{tabular}

\section{d. Interpreting Certification in the USA}

The preliminary steps to be measured in order to be "a certified court interpreter" (Research Division Office of National Center for State Courts, 2019) are as follow:

(a) Reading and speaking regularly the languages

(b) Years of formal education

(c) Specific performance skills based on some elements of innate ability and practice, practice, practice!

(1). Bifurcated Testing Models 
"A bifurcated certification testing method" was applied for "simultaneous interpreting, consecutive interpreting and sight translation" [....] "in two phases" in the study of "America's court interpreter certification exam". "In the three US states" (i.e. New Jersey, New Mexico and Idaho), if passing the simultaneous exercise "as an initial screening instrument", then candidates are allowed to participate in "consecutive interpreting and sight translation" (Wallace, 2013, pp. 67, 70, 76).

(2). Psychometric Validation and Interpreter Certification

In terms of Norma Seltzer's and Margarita Torres-Cartagena's claim for failing the US Federal Court Interpreter Certification Examination (FCICE) two times in 1980, the court decided: Firstly, the Interpreting Studies scholars can make aware of psychometrics from out of scientific consideration and critical perspective to "a certification test" for appropriateness. Secondly, the evidence based on the validity, "an important psychometric property", leads to "a successful defence" (Clifford, 2005, pp. 103-104).

2. Certification Program in Canada

A special committee appointed by CTTIC's Board of Certification selects the examination contents. A candidate can participate in an open book examination of sample texts for a faithful and idiomatic translation to test candidates' ability in analysis and comprehension, as well as their target language mastery. Exams include a section on professional ethics (CTTIC Website, 2019). The whole exam is in one section as follows: Candidates are obliged to translate two texts. One of the texts will be general and compulsory. From two other texts, the candidate must select one and translate it. One of these texts is a little technical/scientific/medical and the other is administrative or economic to some extent. The three texts do not require any specialised terminological knowledge. If the candidate acquires less than $40 \%$ for the compulsory text, the second text will not be scored (CTTIC Website, 2011, 2019).

Two Markers as experienced certified members working independently are appointed for language combinations in accordance with the instructions and marking scale in the CTTIC Board of Certification from different provinces. The mark specified for passing the Translation is 70\%. "Marking Scale Errors" are classified into: "Translation (Comprehension - failure to render the meaning of the original text) and Language (Expression - violation of grammatical and other rules of usage in the target language)". Candidates are not identified to markers (CTTIC Website, 2011, 2019).

From the employers' perspectives, in addition to holding professional certification, three qualifications should be possessed:

(a) Relevant "Previous Experience"

(b) Relevant "University Degree"

(c) Taking an "examination" held by the company or employer (Bowker, 2005, p. 25)

Certification Procedures in Canada

a. On Dossier Certification (Translation, Interpretation and Terminology)

At least two years of experience with a certificate of work experience or at least five years of experience with no certificate of work experience can also be a candidate for this kind of certificate through completing the form of application in the CTTIC Website (CTTIC Website, 2019).

b. Certification by Mentorship

In Québec, OTTIAQ presents the mentorship program leading to certification after holding meetings for at least six months. At the end of the mentorship, if the mentoree provides the required knowledge, s/he will obtain the certification. In New Brunswick, the mentorship program is offered by the CTINB as it follows in OTTIAQ whereas the legislation may be different (CTTIC Website, 2019).

c. Translation Exam

Translation exam is dedicated for candidates not intending to show their aptitude but they can determine their skills for their peers in order to obtain the title of certified translator. It is expected that the candidates accepted in the exam their translation represents "little or no revision". Registration is made in the early fall. Different exams are introduced as follow (CTTIC Website, 2019):

(a) Conference Interpretation Exam Conference interpretation is held by CTTIC for candidates with 200 days of experience or they have acquired an equivalent in this profession.

(b) Court Interpretation Exam Court Interpretation Exam held by CTTIC has several modules to be passed by the candidates as follow: "assessment of language skills, legal terminology and procedure, consecutive interpretation and a simulated trial".

(c) Terminology Exam This exam has been considered for candidates with moderate ability in difficult tasks and doing specialised research in this regard.

3. Certification Program in Australia

Translation Section of NAATI's Manual clarifies different types of errors in difficulty "(from half a mark to five points or more)" classified into "accuracy" (for assessing translating and interpreting tests), "quality of language and technique" presenting guidance for avoiding such errors (Turner, Lai \& Huang, 2010, p. 14). 
a. Two Methods of Translation Test Assessment

Error Deduction and Descriptors-A Comparison of Two Methods of Translation Test Assessment

Two assessment methodologies are represented as: (1) "Error analysis/deduction for NAATI (the Australian National Accreditation Authority for Translators and Interpreters)" and (2) "descriptor-based translation component for UK Institute of Linguists Diploma of Public Service Interpreting (DPSI)" represented a high correlation between these two systems (Turner, Lai \& Huang, 2010, p. 11).

To assess the "translation competence", DPSI assessment system considers a "written translation task" in the following criteria with regard to "four bands of descriptors" (with numerical marks: A: 9-12, B: 7-9, C:4-6 and D:1-3) (Turner, Lai \& Huang, 2010, pp. 15-16): "accuracy/appropriateness of translated text", "cohesion, coherence and genre conventions", and "effectiveness of communication" (UK Institute of Linguists, 2007).

Besides the above criteria, this system pays attention to the "numerical marks" (mentioned above) and "overall grade" in Table V (Turner, Lai \& Huang, 2010, p. 16).

TABLE V

OVERALL GRADE FOR EACH EXAM COMPONENT

\begin{tabular}{|l|l|}
\hline Fail & Fewer than 12 marks overall or fewer than 4 marks in any one category \\
\hline Pass & A minimum of 12 marks overall with no fewer than 4 marks per category \\
\hline Merit & A minimum of 21 marks overall with no fewer than 4 marks per category \\
\hline Distinction & A minimum of 30 marks \\
\hline
\end{tabular}

b. The NAATI Translator Test: Theoretical Bases and Practical Implications

The NAATI Translator Test itself does not have any theoretical bases or perspectives whereas NAATI's translations to the test items are presented based on the translation theories such as "Eugene Nida's formal and dynamic equivalence" (Nida, 1964a; Nida \& Taber, 1969), "Peter Newmark's semantic and communicative translation (Newmark, 1981, 1988) and Mona Baker's approaches to equivalence in translation at different levels (Baker, 1992)" (Ko, 2005, p. 52).

Through the only external factor (like the client's needs, i.e, accurate meaning transfer, naturalness and the clients' specific needs from the translators' point of view) as the examiners' decisions for scoring and "consistency", the NAATI tests are scored by two or three examiners observing the "standard marking guidelines" of NAATI (NAATI, 2002, pp. $15,53)$.

4. Certification Program in China

Considering form and content, CATTI (China Accreditation Test for Translators and Interpreters) examines the reliability, validity, practicality, fairness and washback although the plan follows the improvement for "the amount and types of test items, test content, evaluation rubrics and transparency" (Zou \& Wu, 2015, p. 152) as in Table XI (Zou \& $\mathrm{Wu}, 2015$, p. 155).

TABLE VI

TEST CONTENT AND FORMAT OF THE CATTI

\begin{tabular}{|c|c|c|c|c|c|}
\hline Task & & Input & Format & $\%$ & Length \\
\hline \multirow{3}{*}{$\begin{array}{l}\text { L3 Translation } \\
\text { Comprehensive } \\
\text { Ability }\end{array}$} & $\begin{array}{l}\text { Vocabulary \& } \\
\text { Grammar }\end{array}$ & 60 sentences & MCQ & 60 & \multirow{3}{*}{120} \\
\hline & $\begin{array}{l}\text { Reading } \\
\text { Comprehension }\end{array}$ & 3 texts, 900 words (in total) & MCQ & 30 & \\
\hline & Cloze & A text of about 150 words & MCQ & 10 & \\
\hline \multirow{2}{*}{$\begin{array}{l}\text { L3 Translation } \\
\text { Practice }\end{array}$} & \multirow{2}{*}{ Translation } & A text of about 530 words & E-C & 50 & \multirow{2}{*}{180} \\
\hline & & A text, 400 Chinese Characters & C-E & 50 & \\
\hline \multirow{3}{*}{$\begin{array}{l}\text { L2 Translation } \\
\text { Comprehensive } \\
\text { Ability }\end{array}$} & $\begin{array}{l}\text { Vocabulary \& } \\
\text { Grammar }\end{array}$ & 60 sentences & MCQ & 60 & \multirow{3}{*}{100} \\
\hline & $\begin{array}{l}\text { Reading } \\
\text { Comprehension }\end{array}$ & 3 texts of 1,500 words (in total) & MCQ & 30 & \\
\hline & Cloze & A text of about 250 words & MCQ & 10 & \\
\hline \multirow{2}{*}{$\begin{array}{l}\text { L2 Translation } \\
\text { Practice }\end{array}$} & \multirow{2}{*}{ Translation } & A text of about 530 words & E-C & 50 & \multirow{2}{*}{180} \\
\hline & & A text of 400 Chinese Characters & C-E & 50 & \\
\hline \multirow{4}{*}{$\begin{array}{l}\text { L3 } \\
\text { Interpretation } \\
\text { Comprehensive } \\
\text { Ability }\end{array}$} & \multirow{4}{*}{$\begin{array}{l}\text { Listening, } \\
\text { once }\end{array}$} & 10 short passages ( 20 words) each & True/false & 20 & 10 \\
\hline & & A passage of about 200 words & Gap filling & 20 & 10 \\
\hline & & 3 passages, about 250 words each & MCQ & 30 & 10 \\
\hline & & A text of 500 words & $\begin{array}{l}\text { Summary } \\
\text { writing }\end{array}$ & 30 & 30 \\
\hline \multirow{3}{*}{$\begin{array}{l}\text { L.3 } \\
\text { Interpretation } \\
\text { Practice }\end{array}$} & \multirow[t]{3}{*}{ Interpretation } & $\begin{array}{l}\text { A conversation of } 180 \text { words in } \\
\text { English and Chinese }\end{array}$ & $\mathrm{E}-\mathrm{C} \& \mathrm{C}-\mathrm{E}$ & 20 & 10 \\
\hline & & An English speech, 300 words & E-C & 40 & 10 \\
\hline & & A Chinese speech, 200 Characters & C-E & 40 & 10 \\
\hline \multirow{4}{*}{$\begin{array}{l}\text { L2 } \\
\text { Interpretation } \\
\text { Comprehensive } \\
\text { Ability }\end{array}$} & \multirow{4}{*}{$\begin{array}{l}\text { Listening, } \\
\text { once }\end{array}$} & 10 short passages, 40 words each & True/false & 20 & \multirow{4}{*}{60} \\
\hline & & 10 short passages, 80 words each & MCQ & 20 & \\
\hline & & 4 texts, 900 words in total & MCQ & 40 & \\
\hline & & A text of 600 words & $\begin{array}{l}\text { Summary } \\
\text { writing }\end{array}$ & 20 & \\
\hline
\end{tabular}


Proficiency exams are considered as translation/interpreting proficiency and translation/interpreting practice. Two times a year, test takers take the translation or interpreting exam or both ones. Scores are determined and fees are considered (Zhao \& Gu, 2016).

There are some factors to be considered in scoring translation and interpreting as follow:

The scoring of translation practice largely focuses on four criteria: accuracy, comprehensiveness and smoothness of translation, representation of the original style, and use of punctuation marks. For interpreting, the scoring criteria of verbal answers include fluency, pronunciation and intonation, internal logic, and the absence of omission and wrong interpretation. (Zhao \& Gu, 2016, p. 441)

For this study, "test usefulness" or "language tests qualities" of Bachman and Palmer (1996) were applied to evaluate "reliability and validity, practicality, impact and washback" for CATTI. Moreover, requirements to be a translator and an interpreter (taken from www.catti.net.cn) are mentioned in Table VII (Zhao \& Gu, 2016, pp. 441).

TABLE VII

REQUIREMENTS TO BE A TRANSLATOR AND AN INTERPRETER

\begin{tabular}{|c|c|}
\hline Level & Requirements \\
\hline Senior & $\begin{array}{l}\text { I. long-time devotion to translation and interpreting } \\
\text { 2. encyclopedic knowledge, advanced level and solution to major difficult } \\
\text { problems in translation and interpreting } \\
\text { 3. huge contributions to developing translating and interpreting undertakings } \\
\text { and training translators and interpreters in both theory and practice }\end{array}$ \\
\hline 1 & $\begin{array}{l}\text { 1. encyclopedic knowledge and a high competence for bilingual translation and } \\
\text { interpreting } \\
\text { 2. qualification for extensive and difficult translation and interpreting tasks } \\
\text { 3. capability of interpreting at important international conferences or finalizing } \\
\text { translations }\end{array}$ \\
\hline II & $\begin{array}{l}\text { 1. some scientific and cultural knowledge } \\
\text { 2. a good competence for bilingual translation and interpreting } \\
\text { 3. capability of translating and interpreting in certain areas and with some } \\
\text { degree of difficulties }\end{array}$ \\
\hline III & $\begin{array}{l}\text { I. rudimentary scientific and cultural knowledge } \\
\text { 2. an average competence for bilingual translation and interpreting } \\
\text { 3. ability to finish ordinary translation work }\end{array}$ \\
\hline
\end{tabular}

a. Translation Credentialing in Hong Kong: Institute of Linguists (IoL)

IDBC (International Diploma in Bilingual Communication) evaluates "receptive and productive skills" for 4 modules and 5 optional modules (IoL, 2010) as follow in Table 8 (Wong, n.d., pp. 7-8).

TABLE VIII

RECEPTIVE AND PRODUCTIVE SKILLS IN BILINGUAL COMMUNICATION

\begin{tabular}{|c|c|}
\hline IDBC & Detail \\
\hline $\begin{array}{l}\text { Module 1: } \\
\text { Summary in Chinese }-2 \frac{1}{2} \text { hours }\end{array}$ & $\begin{array}{l}\text { Focused summary/report in Chinese based on specific brief in Chinese and } \\
\text { using dossier of 3-5 authentic texts in English. }\end{array}$ \\
\hline $\begin{array}{l}\text { Module 2: } \\
\text { Business Writing and Communications in English }-2 \frac{1}{2} \text { hours }\end{array}$ & $\begin{array}{l}\text { Report/summary/outline in English based on a brief in English and material in } \\
\text { Chinese. } \\
\text { Written business communications in English. }\end{array}$ \\
\hline $\begin{array}{l}\text { Module 3: } \\
\text { Translation }-3 \text { hours }\end{array}$ & Translation into English and Chinese (11/2 hours for each translation). \\
\hline $\begin{array}{l}\text { Module 4: } \\
\text { Interpreting - } 50 \text { minutes }\end{array}$ & $\begin{array}{l}\text { Consecutive Liaison Interpreting: } 10 \text { minutes preparation time and } 20 \text { minutes } \\
\text { interpreting. Sight Translation: } 5 \text { minutes preparation time, } 5 \text { minutes sight } \\
\text { translation, in each language. }\end{array}$ \\
\hline \multicolumn{2}{|l|}{ ALL MODULES PASSED: CERTIFICATE AWARDED } \\
\hline $\begin{array}{l}\text { Module 5: } \\
\text { WRITTEN PROJECT OR PRESENTATION MODULE } \\
\text { [Optional] }\end{array}$ & $\begin{array}{l}\text { Written Project (c. } 3000 \text { words) or } 10 \text { minute Oral Presentation on work- } \\
\text { related topic followed by a question and answer session of } 5 \text { minutes. } \\
\text { Certificate endorsed with topic of project or presentation. }\end{array}$ \\
\hline
\end{tabular}

b. Practicality and Authenticity in Accreditation Tests for Interpreters

Practicality is referred to as Time "constraints, financial limitations", the ease of a test administration and scoring considered essential practice in designing a test regarding "usefulness and washback effect" (Chen, 2009, 2014, p. 271). Three questions are appeared with regard to the authenticity in China:

(a) Can accreditation test be found authentic for usefulness?

(b) How can and should the authenticity be in the tests?

(c) How would practicality be "as a test quality" "in authentic accreditation test"? (Chen, 2009, 2014, p. 257)

c. Hong Kong Judiciary and Hong Kong Translation Society (HKTS)

Hong Kong Court interpreters shall possess the following criteria:

(a) A Hong Kong degree 
(b)Level 2 in English and Chinese as well as "a pass result in the Aptitude Test in the Common Recruitment Examination". (Wong, n.d., p. 11)

Training "during probation period" is to be "training and on-the-job training", emphasizing competency-based performance for each "aspect" such as "court interpreting skills", "written work, etc." inspecting their performance during the year (Wong, n.d., p. 11).

The Diploma examination of Hong Kong Translation Society (HKTS) was introduced as a "bilingual test" for "translation skills" following the objectives mentioned below (Wong, n.d., pp. 8-9):

(a) Fluency;

(b) Accuracy;

(c) Cultural knowledge of Hong Kong, China and international affairs

The most important criteria of a legal translator are as follow:

(a) Membership, either in the organisation offering the certification or in another translation and interpreting $(T \& I)$ organization

(b) Education

(c) Experience

(d) Mandatory seminar on ethics or best practices

(e) Screening tests in the language of the given country

(f) References or referrals from peers, clients, or employers

(g) Mandatory mentoring program (Wong, n.d., p. 15)

d. Proposed Accreditation System for Legal Translators in Hong Kong

(a) General Legal Knowledge and Terminology (30\%)

(b) Legal Translation $(60 \%)$

(c) Professional Ethics (10\%) (Fai, n.d., p. 8)

Other Recommendation

(a) The accreditation body of the proposed system may engage the Hong Kong Examinations and Assessment Authority (HKEAA) to administer exams on its behalf.

(b) HKEAA will protect the integrity of the examination procedures by strictly.

(c) Accreditation body can still benefit from the expertise of the HKEAA in organizing examinations (Fai, n.d., p. 10).

\section{Certification Program in Taiwan}

ECTICE interpretation exam consists of an English competency paper-and-pencil test and two interpretation tests, including a short consecutive interpretation (short CI) test and a long consecutive interpretation (long CI) test. The first exam is a criterion for accepting to take the two interpretation tests. Each interpretation test for generalists includes two English passages into Mandarin and two Chinese passages into English. In short CI test, each passage length has been considered for 3 minutes, and in long CI test, it has been approximately 5 minutes (Ministry of Education, 2009b). Topics of these two tests do not belong to any technical one. "Brief summary of the content", "difficult terms and their equivalents" are mentioned in the tests. A digital recordings of the test-takers' interpretations for Aural test items are converted into audio files. The time for interpretation of each segment is previously determined (Liu, 2013, p. 164).

"Two senior interpreter trainers as the test writers of ECTICE interpretation tests choose among four sets of tests and decide on one set for each of the short and long CI tests. The chosen set of tests are then recorded as audio files, with the speech rate set at 100 to 110 English words per minute or 160 to 175 Chinese characters per minute (Ministry of Education, 2009b)" (Liu, 2013, p. 165).

Suggestions for Assessing Interpretation Skills

(a) For "a holistic scoring method", specify the "criteria with clear descriptors".

(b) To apply "an analytical scoring method" besides "the clear descriptors for all criteria", calculation of "the sub-score of each criterion" should be "clear".

(c) For fidelity, "divide the source text into smaller rating units".

(d) For fidelity of interpretation, have clear "important and secondary meaning units" or errors.

(e) Rater training helps the rater for the assurance of the "rating process". Allocating time, the raters can practice varieties of rating for each level, and discussion on rating leads to "ease and consistency". The role of rater training "for reliable and valid ratings" has not been specified and should do more research study (Liu, 2013, p. 175).

6. Certification Program in Korea

Assessing the Impact of Text Length on Consecutive Interpreting

"To assess" the consecutive interpreting from English into Korean for "the students' performance" from the Korean as the mother language to English, the PAT (Performance Assessment Tool) (Choi, 2005) specifies the scores in number for "accuracy, expression and presentation". "The average scores between the two raters" for "the first 2 minutes and 30 seconds of the source text" were analyzed statistically (Choi, 2013, pp. 87-88). Each rater did the assessment of the "student performance", and the result was made by the "reliability test" (Choi, 2013, p. 90).

7. Certification Program in Finland 
The examination for the authorised translator includes "two translation assignments and a test on the candidate's knowledge of the authorised translator's professional practices". The translation examination was made by the computer, and during the examination, all types of dictionaries, any reference and the Internet can be applied but software such as "machine translation" and "translation memories" as well as "professional contacts" are not allowed. Regarding the test on "professional practices", "multiple-choice test format" with "three choices" is considered while the use of the Internet is avoided. For this test, two evaluators were appointed by the recognition of the Finnish National Board of Education. These evaluators "prepared and evaluated" the test items (Salmi \& Penttila, 2013, pp. 115, 123).

8. Certification Program in Iran

Certification Program and Quality Assessment

In Iran, a candidate accepted as a Certified Translator shall also work as a Certified Interpreter. At first stage, Sanjesh organisation announces the necessity for recruitment of certified translators assessed by the Justice Administration, and administers the nationwide examination. In addition, Sanjesh Organisation selects some exam designers, markers or evaluators for designing, correcting or evaluating the candidates' exams.

Through the exam procedure to a Multiple Choice Test, including Grammar, Vocabulary and Reading Comprehension, a technical translation assignment with 14 paragraphs translation in half from English to other languages and half vice versa (based on obtaining 50\% score for each Section 1 and Section 2 of the exam respectively), and the interview in comparison with "other institutes around the world and also with the standards of American Translator Association (ATA)" (Zafarghadni \& Sharifi, 2008, p. 28), the most translators do not accept the stages of the assessment program.

\section{B. General Studies of Certification Program for Certified Interpreters}

The bands for the levels of quality in the Lee's study for Interpreting Performance Assessment were described in Table IX (Lee, 2008, 2014, pp. 172-173).

TABLE IX.

RATING SCALES (BANDS)

\begin{tabular}{|c|c|c|c|}
\hline CRITERIA (EXAMPLES) & BAND & EXTENT OF FAITHFUL DELIVERY OF MESSAGE & LISTENING ABILITY \\
\hline \multirow{3}{*}{$\begin{array}{l}\text { Accuracy: } \\
\text { - the quality of faithfully conveying } \\
\text { the message of the speech with } \\
\text { semantic and pragmatic equivalence } \\
\text { i.e. reproducing the same meaning } \\
\text { and intended effect }\end{array}$} & 6 & The message was delivered accurately with intended effect. & $\begin{array}{l}\text { Complete understanding of the message } \\
\text { of the original speech }\end{array}$ \\
\hline & 5 & $\begin{array}{l}\text { The message was generally delivered with intended effect but a few } \\
\text { minor deviations from the source text were found, which did not } \\
\text { significantly affect the overall meaning or coherence. }\end{array}$ & $\begin{array}{l}\text { Good understanding of the message of } \\
\text { the original speech }\end{array}$ \\
\hline & 4 & $\begin{array}{l}\text { The overall message was delivered but some deviations from the } \\
\text { source text with an impact on the meaning and effect but coherence } \\
\text { was maintained. }\end{array}$ & $\begin{array}{l}\text { Adequate understanding of the message } \\
\text { of the original speech }\end{array}$ \\
\hline \multirow{2}{*}{$\begin{array}{l}\text { - Deviations from the ST should be } \\
\text { considered in terms of the effect on } \\
\text { the coherence/logic and faithful } \\
\text { rendering of the message }\end{array}$} & 3 & $\begin{array}{l}\text { The message was delivered inaccurately with many deviations from } \\
\text { the source text and coherence was compromised. }\end{array}$ & $\begin{array}{l}\text { Inadequate understanding of the } \\
\text { message of the original speech }\end{array}$ \\
\hline & 2 & $\begin{array}{l}\text { The message was delivered inaccurately with serious deviations } \\
\text { from the source text and incoherence. }\end{array}$ & $\begin{array}{l}\text { Poor understanding of the message of } \\
\text { the original speech }\end{array}$ \\
\hline \multirow{3}{*}{$\begin{array}{l}\text { - Examples of deviations: } \\
\text { omissions, additions, and } \\
\text { unjustifiable changes of the meaning }\end{array}$} & 1 & $\begin{array}{l}\text { The interpreted message was incoherent and completely inconsistent } \\
\text { with the source text. }\end{array}$ & $\begin{array}{l}\text { Very limited understanding of the } \\
\text { message of the original speech }\end{array}$ \\
\hline & 0 & \multicolumn{2}{|l|}{ Test abandoned/unfinished. } \\
\hline & \multicolumn{2}{|l|}{ Mark } & 16 \\
\hline CRITERIA (EXAMPLES) & BAND & GRADUATION OF TARGET LANGUAGE PRODUCTION & $\begin{array}{l}\text { TARGET LANGUAGE } \\
\text { PROFICIENCY }\end{array}$ \\
\hline \multirow{2}{*}{$\begin{array}{l}\text { TL Quality: } \\
\text { - the quality of rendering in TL } \\
\text { needs to be linguistically correct and } \\
\text { appropriate in the context }\end{array}$} & 6 & $\begin{array}{l}\text { Excellent target language production with few linguistic errors and } \\
\text { appropriate target language expressions. }\end{array}$ & Excellent language proficiency \\
\hline & 5 & $\begin{array}{l}\text { Very good target language production with a few minor linguistic } \\
\text { errors that do not hinder immediate target language comprehension } \\
\text { and generally appropriate target language expressions. }\end{array}$ & Very good language proficiency \\
\hline
\end{tabular}




\begin{tabular}{|c|c|c|c|}
\hline \multirow{6}{*}{$\begin{array}{l}\text { Examples of deviations from } \\
\text { language norms : incorrect } \\
\text { pronunciation, accent, and stress; } \\
\text { incorrect grammar, unidiomatic } \\
\text { language; interference from the } \\
\text { source language; inappropriate } \\
\text { language in the target culture and for } \\
\text { the target audience (register misuse) }\end{array}$} & 4 & $\begin{array}{l}\text { Good target language production with a few linguistic errors that } \\
\text { may hinder immediate comprehension, but quite understandable. A } \\
\text { few minor inappropriate target language expressions were found. }\end{array}$ & Good language proficiency \\
\hline & 3 & $\begin{array}{l}\text { Adequate target language production with some linguistic errors that } \\
\text { hinder comprehension and some inappropriate target language } \\
\text { expressions. }\end{array}$ & Adequate language proficiency \\
\hline & 2 & $\begin{array}{l}\text { Inadequate target language production with many linguistic errors } \\
\text { and inappropriate target language expressions were consistently } \\
\text { found. }\end{array}$ & Inadequate language proficiency \\
\hline & 1 & $\begin{array}{l}\text { Poor target language production with inappropriate target language } \\
\text { expressions }\end{array}$ & Poor language proficiency \\
\hline & 0 & \multicolumn{2}{|l|}{ Test abandoned/unfinished } \\
\hline & \multicolumn{2}{|l|}{ Mark } & $/ 6$ \\
\hline CRITERIA (EXAMPLES) & BAND & EXTENT OF DELIVERY & PUBLIC SPEAKING ABILITY \\
\hline \multirow{2}{*}{$\begin{array}{l}\text { Delivery: } \\
\text {-quality of good public speaking }\end{array}$} & 3 & Excellent delivery with few deviations & Excellent presentation/communication \\
\hline & 2 & Good delivery with a few deviations & Good presentation/communication \\
\hline - successful communication & 1 & Poor delivery with some deviations & Poor presentation/communication \\
\hline \multirow{2}{*}{$\begin{array}{l}\text { Examples of deviations: inarticulate } \\
\text { speech, pauses, hesitation, false } \\
\text { starts, fillers, irritating noise, } \\
\text { repetition, excessive repairs or self- } \\
\text { correction, unconvincing voice } \\
\text { quality and monotonous intonation, } \\
\& \text { irritatingly slow speech rate }\end{array}$} & 0 & \multicolumn{2}{|l|}{ Test abandoned/unfinished } \\
\hline & Mark & \multicolumn{2}{|r|}{$/ 3$} \\
\hline Total mark & \multicolumn{3}{|r|}{$/ 15$} \\
\hline
\end{tabular}

1. Selection Tests for Trainee Conference Interpreters

Gerver, Longley, Long, and Lambert (1989) argued that a collection of 'psychometric' or 'objective' tests was designed for "simultaneous and consecutive interpreter-trainee candidates", consisting of 12 questions based on "text materials, linguistic subskills or speed-stress" (p. 724). Considering the articles and interviews with interpreters, they mentioned the following qualifications for an interpreter:

(a) Profound knowledge of active and passive languages and cultures

(b) Ability to grasp rapidly and convey the essential meaning of what is being said

(c) Ability to project information with confidence, coupled with a good voice

(d) Wide general knowledge and interests, and a willingness to acquire new information

(e) Ability to work as a member of a team (Gerver et al., 1989, p. 724)

2. Unpacking Delivery Criteria in Interpreting Quality Assessment and Simultaneous Interpreting

The main criteria for Interpreting Quality Assessment in the studies have been made until now would be "accuracy", "fluency" and "pleasant voice" (pronunciation: Accent, Intonation and Diction) (Iglesias Fernández, 2013, pp. 54, 5859).

3. Building the Validity Foundation for Interpreter Certification Performance Testing

To provide evidence for "rater reliability" and "score generalizability", a methodological process evaluates "multifaceted Rasch measurement" and "generalizability theory". The research data is the score analyses. The study represented reliable results for the rating design whereas one of the raters was problematic because of non-selfconsistency and biased scores to a large proportion of the interpreters. According to the results, number of raters or tasks improved "score reliability for each rating dimension, but the relative efficiency was different across the dimensions" (Han, 2015, p. 22).

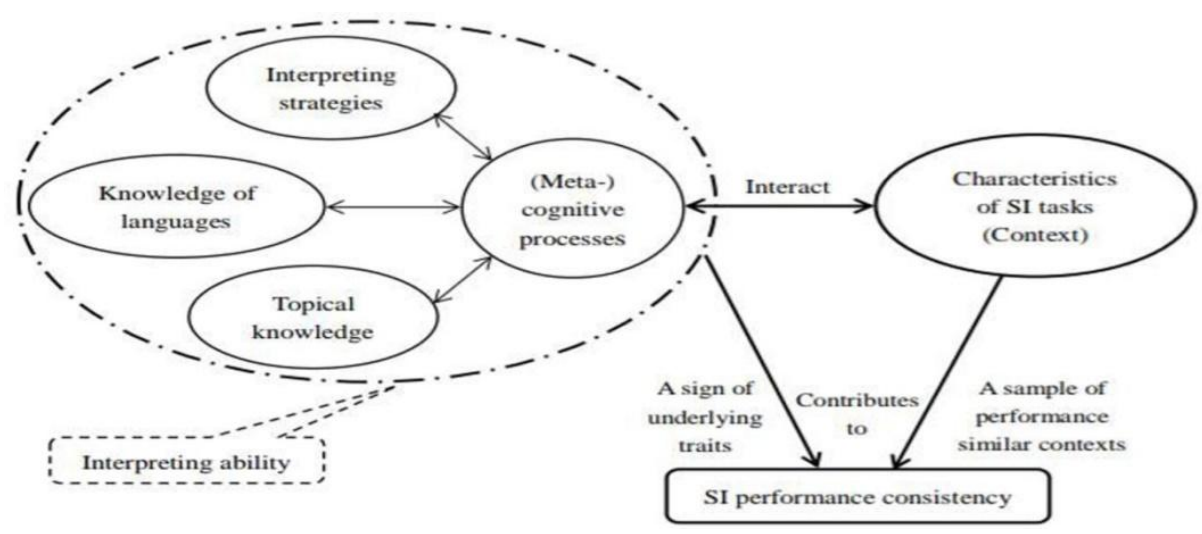

Figure 4. An interactionist approach to interpreting performance consistency (Han, 2015, p. 68) 


\section{Methodology}

This study considered a review research based on the narrative type. This research design represents the qualitative one. Some studies were selected, summarized and compared with regard to the researchers' experience, and models presented by other researchers in the related field. The samples consisted of the most important certification programs for certified translators and interpreters in different countries. The data were gathered by analysis and comparison of different systems through studying the related websites and articles.

\section{RESUlts AND Discussion}

\section{Comparative Studies in Certification Programs}

Comparing 21 countries (mentioned in the following paragraph) certification procedures, "New World countries such as Australia, Canada," and the United States of America hold single tests based on "general or specialised ability, or mode and context of inter-lingual transfer", and the other countries such as "European and East Asian countries", "minimum standards" of ability are required to be tested via long-term training like studying in postgraduate levels in the related fields of translator and interpreter (Hlavac, 2013, p. 32).

Table X (Hlavac, 2013, p. 38) demonstrates "Features of Testing Procedures" of "21 sample organisations", (including Argentina, Australia, Austria, Belgium, the Netherlands, Brazil, Canada, China, Croatia, Egypt, Germany, Ireland, Japan, Mexico, Norway, South Africa, Spain, Sweden, Finland, UK, the United States).

TABLE X

FEATURES Of TESTING PROCEDURES REPORTED From 21 SAMPLE ORGANISATIONS

\begin{tabular}{|c|c|c|c|}
\hline Feature & Yes & No & $\begin{array}{l}\text { No information } \\
\text { available / Not } \\
\text { applicable }\end{array}$ \\
\hline $\begin{array}{l}\text { Certification conducted by a } \\
\text { governmental organisation }\end{array}$ & 8 & 13 & 0 \\
\hline Language proficiency test & 7 & 14 & 0 \\
\hline Formal examination & 18 & 3 & 0 \\
\hline Separate portfolio & 2 & 19 & 0 \\
\hline Minimum age & 9 & 12 & 0 \\
\hline $\begin{array}{l}\text { Membership of accrediting association } \\
\text { obligatory }\end{array}$ & 6 & 8 & 7 \\
\hline Minimum experience level & 7 & 13 & 1 \\
\hline Minimum education level & 10 & 8 & 3 \\
\hline Lack of criminal record & 6 & 10 & 5 \\
\hline Sign-language interpreting & 4 & 10 & 7 \\
\hline Video or audio recording of exam & 2 & 2 & 17 \\
\hline Availability of practice/sample tests & 8 & 4 & 9 \\
\hline Permission to use resources for exam & 7 & 2 & 12 \\
\hline Available statistics on pass rate & 0 & 14 & 7 \\
\hline Details of the content of translation texts & 8 & 7 & 6 \\
\hline $\begin{array}{l}\text { Details of the content of the interpreting } \\
\text { test }\end{array}$ & 4 & 14 & 3 \\
\hline Test / exam contains a general component & 6 & 6 & 9 \\
\hline $\begin{array}{l}\text { Test / exam contains specialist } \\
\text { components }\end{array}$ & 13 & 6 & 2 \\
\hline Test / exam accompanied by training & 1 & 18 & 2 \\
\hline Availability of any training & 3 & 12 & 6 \\
\hline Conferral of official legal title & 10 & 9 & 2 \\
\hline $\begin{array}{l}\text { Re-registration/re-validation of } \\
\text { certification required }\end{array}$ & 7 & 9 & 5 \\
\hline Availability of examiners' manual & 1 & 1 & 19 \\
\hline
\end{tabular}

In Australia, Canada, the USA and Ukraine, the process of the examination can be made in terms of "pragmatic, needs-based and social policies" for translation and interpreting. In Ukraine, "translators must pass a certification exam" whereas interpreters must possess a minimum of 100 hours interpreting or "recommendations" from "service-users" (Skyba, 2014, p. 63).

The test should evaluate not only the knowledge but also the ethics and socio-cultural aspects in the Ukrainian societies or other communities and countries. The certification is issued in terms of a "particular field or industry, health or medical interpreters and translators, legal or judiciary interpreters" (Skyba, 2014, p. 63).

CATTI measures "competence" of the Chinese language in comparison with seven languages as in languages like "English, Japanese, French, Arabic, Russian, German or Spanish. In this regard, tests for interpreting, simultaneous and consecutive interpreting are focused. The test is applied in a variety of fields such as "business, government, academia, and media" (Zhao \& Gu, 2016, p. 439), but IoL does not hold "a competency test" for legal translation, and a "bilingual 
test" for "translation skills" is of paramount (Wong, n.d., p. 8, 11). Another main challenge would be regarded as the codes of ethics resulted from different research studies (e.g. Scanlon \& Glover, 1994; Adams, Tashchian \& Shore, 2001; Wotruba, Chenko \& Loe, 2001). Sook (2015) mentioned lack of ethics criteria for translators in Iran (Kafi, Khoshsaligheh \& Hashemi, 2018, p. 100).

The "organisations and associations" mentioned in this paragraph consider the "credentialing examinations". These examinations consist of some passages "from the source (mother) language to target language or vice versa". But some other organs such as NAJIT (National Association of Judiciary Interpreters and Translators) of USA and CATTI (China Aptitude Test for Translators and Interpreters) follow the multiple choice test format like the Graduate Record Examination (GRE). The NAJIT test format contains "reading comprehension, grammar, idiomatic expressions, and general as well as specialised legal vocabulary". The only difference of the NAJIT testing system regarding examination could be considered as the minimum $60 \%$ of its language system which belongs to the one of the courtroom (NAJIT, 2010) (Wong, n.d., pp. 16-17).

1. Examination Certificate

Beside certification exam, some certification processes such as "certification on dossier" and "by mentorship" are administered in Canada for obtaining the certificate of certified translators, certified interpreters and certified terminologists (Skyba, 2014, p. 63).

The certification procedure is "customary in common law countries, such as USA, UK and Canada" turned over a "professional association". In contrast, this procedure is performed by employment process "in civil law countries, such as China" turned over "a government body or quasi-government body" (Wong, n.d., p. 15). See Fig. 5 (Han, 2015 , pp. 269-271) in order to get familiar with some of the certificate tests and their raters' issues.

\begin{tabular}{|c|c|c|c|c|}
\hline Country & Certification body/test & Literature reviewed & $\begin{array}{l}\text { Model of rater } \\
\text { reliability estimation }\end{array}$ & $\begin{array}{c}\text { Rater training? \& } \\
\text { Rater reliability estimate (RRE) }\end{array}$ \\
\hline Australia & $\begin{array}{l}\text { - National Accreditation Authority for } \\
\text { Translators and Interpreters (NAATI) } \dagger^{\dagger \dagger}\end{array}$ & $\begin{array}{l}\text { * } \text { Hale \& Campbell (2003), Hale et al. } \\
\text { (2012), NAATI (2013), Turner et al. } \\
\text { (2010) }\end{array}$ & - Intra- \& inter-rater & $\begin{array}{l}\text { - Yes, but details cannot be accessed } \\
\text { (internal report). } \\
\text { - RRE: Inaccessible. }\end{array}$ \\
\hline $\begin{array}{l}\text { Belgium } \\
\text { (Flanders) }\end{array}$ & $\begin{array}{l}\text { - Social Interpreter Certification Examination } \\
\text { (SICE) by Flemish Central Support Cel } \\
(\mathrm{COC}) \dagger \dagger\end{array}$ & ell $*$ Vermeiren et al. (2009) & - Intra- \& inter-rater & $\begin{array}{l}\text { - Yes, but no detailed descriptions. } \\
\text { - RRE: No indices provided. }\end{array}$ \\
\hline Canada & $\begin{array}{l}\text { - Signed language interpreter certification tes } \\
\text { by the Association of Visual Language } \\
\text { Interpreters of Canada (AVLIC) } \dagger \\
\text { - Conference Interpretation Examination by } \\
\text { the Canadian Translators, Terminologists } \\
\text { and Interpreters Council (CTTIC) } \dagger \dagger\end{array}$ & $\begin{array}{l}\text { *Russell \& Malcolm (2009) } \\
{ }^{*} \text { CTTIC website }{ }^{\mathrm{a}}\end{array}$ & - Inter-rater agreement & $\begin{array}{l}\text { - Yes, detailed training procedures. } \\
\text { - RRE: Above } 95 \% \text { agreement on } \\
\text { pass/fail decision. }\end{array}$ \\
\hline$\cdots$ & & & & \\
\hline Country & Certification body/test & Literature reviewed & $\begin{array}{l}\text { Model of rater } \\
\text { reliability estimation }\end{array}$ & $\begin{array}{l}\text { Rater training? \& } \\
\text { Rater reliability estimate (RRE) }\end{array}$ \\
\hline China & $\begin{array}{l}\text { - China Accreditation Tests for Translators } \\
\text { and Interpreters (CATTI) } \dagger \\
\text { - National Accreditation Examinations for } \\
\text { Translators and Interpreters (NAETI) } \dagger \dagger\end{array}$ & $\begin{array}{l}\text { * Cai (2007), Cai (2009), Office of CATTI } \\
\text { (2005), Lu et al. (2007), CATTI website } \\
\text { * NAETI website }\end{array}$ & • Inaccessible & - Inaccessible. \\
\hline Norway & $\begin{array}{l}\text { - Norwegian Interpreter Certification } \\
\text { Examination (NICE) } \dagger^{\dagger+}\end{array}$ & *Mortensen $(1998,2001)$ & $\begin{array}{l}\text { - General concept of } \\
\text { reliability }\end{array}$ & $\begin{array}{l}\text { - Yes, but no detailed descriptions. } \\
\text { - RRE: Inaccessible. }\end{array}$ \\
\hline South & - Simultaneous Interpreter Accreditation & & & \\
\hline Africa & $\begin{array}{l}\text { Testing by South African Translators' } \\
\text { Institute (SATI) } \dagger+\end{array}$ & *SATI website ${ }^{d}$, SATI $(2007 a, 2007$ b) & - Inaccessible & - Inaccessible \\
\hline UK & $\begin{array}{l}\text { - Diploma in Public Service Interpreting } \\
\text { (DPSI) by loL Educational Trust } \\
\text { (loLET) } \dagger+\end{array}$ & * loL Educational Trust (2010) & - Inter-rater & $\begin{array}{l}\text { - Yes, training \& monitoring, no } \\
\text { detailed descriptions. } \\
\text { - RRE: Inaccessible. }\end{array}$ \\
\hline
\end{tabular}




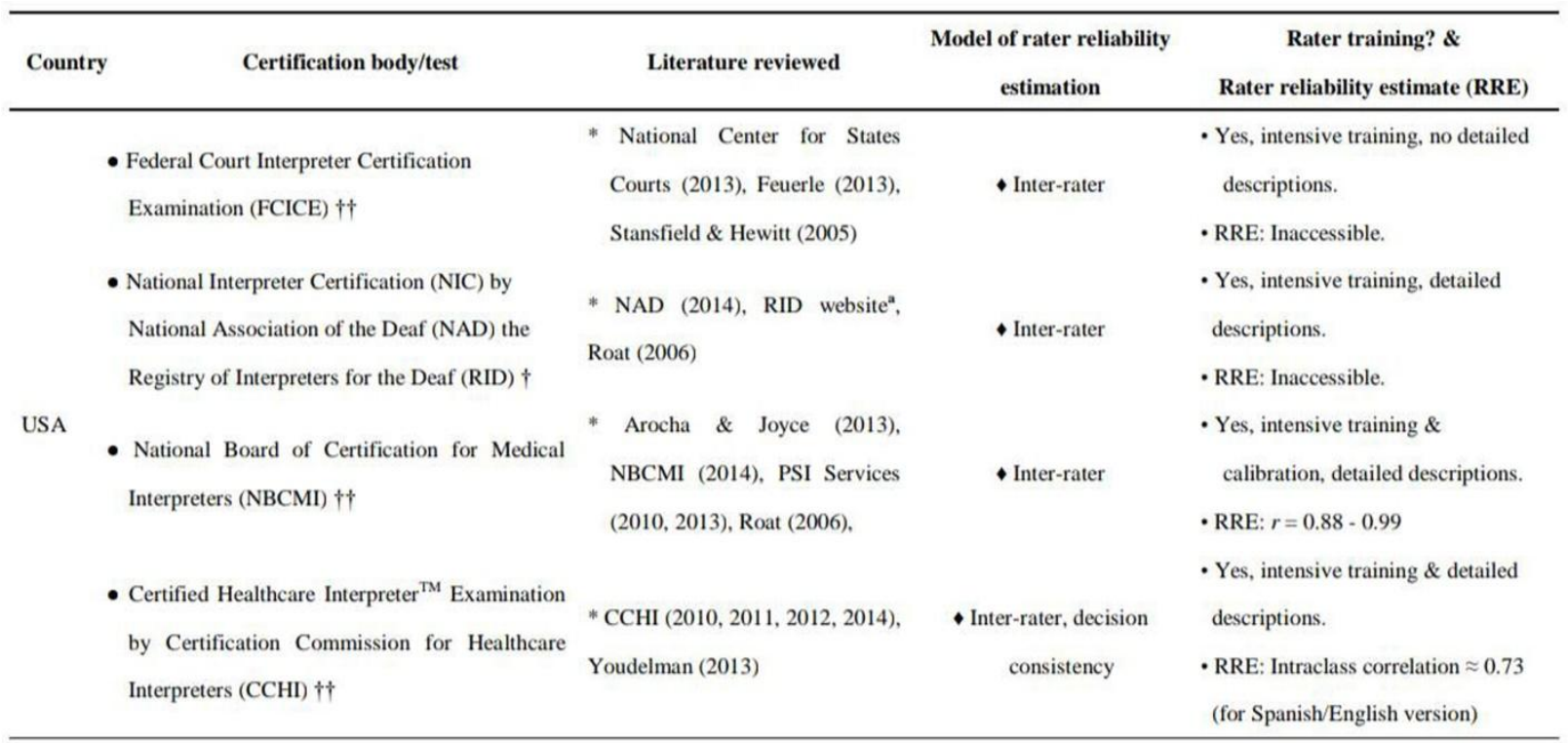

Note.

a. See CTTIC Website: http://www.cttic.org/certification.asp

b. CATTI Website: http://www.catti.net.cn/node_74539.htm

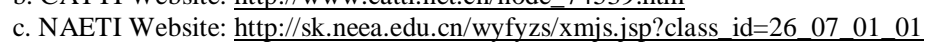

d. SATI Website: http://translators.org.za/sati_cms/index.php?frontend_action=display_text_content\&content_id=1783

$\dagger \dagger$ Certifying both spoken \& sign language interpreters; $\dagger \dagger$ Certifying spoken language interpreters; $\dagger$ Certifying sign language interpreters. e. RID Website: http://rid.org/education/testing/index.cfm/AID/86

Figure 5. Reviewed certification tests and practice of rater training and calibration

Through the examination administrators' answers to the detailed questionnaire and comparison with the standards of ATA, no "professional standards" in designing test items are applied in Iran. Moreover, the assessment procedure relies on the examining board although there are "parameters of translation quality assessment" and standards "in constructing and administering the translation certification in other countries". For the validity and reliability of the tests, the answers clarify "a lack of evidence for the empirical validity and the reliability ......" (Zafarghadni \& Sharifi, 2008, p. 28).

Member bodies of CTTIC administer a translation exam through the Board of Certification each year throughout the country at the same time, and other exams such as conference interpretation, court interpretation and terminology are held based on demand. In Ontario, Québec, New Brunswick and British Columbia respectively titled ATIO, OTTIAQ, CTINB and STIBC, the persons involved in these professions obtained their certificate after many years of work experience together with provincial leaders in the relevant profession. Most other member organisations are trying to obtain working in these professions in their province or territory (CTTIC Website, 2019).

The revision of Final Diploma in English and Chinese (FDEC) led to the International Diploma in Bilingual Communication (IDBC) for professional and business materials in the fluency of written and spoken languages (Wong, n.d., pp. 7-8). The license of different certified translation jobs is granted by the provincial regulatory bodies and this council administers the candidates' exam (See more information: http://www.cttic.org/certification.asp), whereas, in Iran, Sanjesh Organisation affiliated to the Ministry of Science, Research and Technology administers the exam and its standardisation, and the Department of Official Translators Affairs of the Judiciary of Iran issues the license. The Department of Official Translators Affairs of Iran was established to actually perform the affairs related to the Official/Certified Translation Offices and Official/Certified Translators from interview to trainee and during the time of working as an Official Translator.

2. Organisations, Associations and Institutes

There are different bodies of the most popular certification systems related to the translation and interpreting, including two international organisations: European Union (EU) and the United Nations (UN), one International Translators Association (ITA), one International Federation of Translators (FIT), China Accreditation/Aptitude Test for Translators and Interpreters (CATTI) controlled by "China Foreign Languages Publishing Administration (CFLPA)" supervised by the "Ministry of Human Resources and Social Security of the People's Republic of China" (Zhao \& Gu, 2016, p. 439), the Australian National Accreditation Authority for Translators and Interpreters (NAATI), American Translators Association (ATA), National Association of Judiciary Interpreters and Translators of the USA (NAJIT), US Language Service Providers, National Accreditation Examinations for Translators and Interpreters (NAETI) of China, UK Institute of Linguists (IoL) issued a diploma titled "Diploma of Public Service Interpreting" (DPSI) (Wong, n.d., p. 11), Institute of Translation and Interpreting (ITI) of the United Kingdom, Finnish National Board of Education (for administration of Finnish Authorisation Exam), eight interpreting centres in Finland under the supervision of municipalities such as the Finnish Association of Translators and Interpreters, Municipal Interpreting Centres, etc. (infoFinland.fi Website, 2019), and in Canada, each province has its own specific certified translators, terminologists 
and interpreters association called ATIA, ATIO, CTINB, OTT, IAQ, ATIM, ATIS, STIBC under the control of Canadian Translators, Terminologists and Interpreters Council. There is also a CTTIC's Board of Certification. The credentialing system in Hong Kong is IoL-"a United Kingdom linguists association" (Wong, n.d., p. 11). In some countries, governmental organisations administer the certification process to confer the certificate (Skyba, 2014, p. 63). In Iran, these organs or bodies are considered as the Department of Official Translators Affairs of the Judiciary of Iran, Iranian Association of Certified Translators and Interpreters (IACTI) and Iranian Translators and Interpreters Association (ITIA). The main challenge in Iran for the translation profession is the lack of support of the translation guild. As such, Sook (2015) argues that there is the same condition in Korea and Malaysia. Setton and Lianliang (2011) state that there are "very few professional translators" in Taiwan to be a member "in any local or national translator association". Specifically, there is "lack of specific market entrance criteria for translators"(Kafi, Khoshsaligheh \& Hashemi, 2018, pp. 99-100).

\section{CONCLUSION}

Generally speaking, the Certified Translators and Interpreters' Recruitment System has not yet had a general framework in terms of the different countries in order to have a wide view of standardisation. It is not justifiable for any person professional in translation or knows even a little knowledge of translation, this idea that every translator is interpreter or vice versa as we can see this process in some countries such as Iran. Some countries should also find a way to make the content or material of the Examination to be closely related to the job the candidates supposed to take over. If the material of the exam should not be related to job, then the candidates accepted as Certified Translators do not have any knowledge background for the job they have accessed. It is important to know that it is impossible for all persons in the world to know a language completely and thoroughly, and the most important point is that this exam is going to find and select the best professional translators in a specific language for a specific profession since the specific knowledge is required not the general one. This issue determines the importance of the test content for the future job as a profession.

In order to possess the professional or certified translators and interpreters for a government body, an institute or an association, different certification programs or tests studied in different researches were collected. Then they were compared, discussed and evaluated in order to find a more comprehensive system of assessment as general framework or model of examination assessment for Certified Translation and Interpreting Assessment drawn in tables (shown in the Tables XI and XII) in this regard. The benefits of obtaining the certification would be to formalise "services", measure "own abilities", and demonstrate "ourselves to others" (Skyba, 2014, p. 63). Main role of CTTIC is to achieve two objectives for application of certification: "to standardise methods of entry to the profession and to monitor the skills of translators" in provincial and territorial organisations (CTTIC Website, 2019).

TABLE XI

A MOdel OF CERTIFICATION PROGRAM FOR CERTIFIED TRANSLATORS

\begin{tabular}{|l|l|l|l|l|l|l|}
\hline Exam (Test/Task) & $\begin{array}{l}\text { Mdvanced, } \\
\text { Level }\end{array}$ & $\begin{array}{l}\text { Inimum knowledge, } \\
\text { knowledge, } \\
\text { specific } \\
\text { Knowledge } \\
\text { highly professional }\end{array}$ & $\begin{array}{l}\text { Training/herwise) } \\
\text { mentorshi } \\
\mathbf{p}\end{array}$ & $\begin{array}{l}\text { Accreditation } \\
\text { No exam }\end{array}$ \\
\hline $\begin{array}{l}\text { Type of } \\
\text { Exam/Task }\end{array}$ & $\begin{array}{l}\text { Proficiency/competency/ } \\
\text { translation/writtenTest }\end{array}$ & $\begin{array}{l}\text { Translation (whole } \\
\text { or some) }\end{array}$ & & & $\begin{array}{l}\text { University } \\
\text { degree/ } \\
\text { dossier }\end{array}$ \\
\hline
\end{tabular}

\begin{tabular}{|l|l|l|l|l|l|l|}
\hline \multicolumn{9}{|l|}{ Proficiency (Candidate) } \\
\hline Language & Translation & Culture & Skopos & Tools & Exam/no exam & A team worker \\
\hline Theory \& practice & Comprehension & Interpreting & Membership & Education & Experience & Ethics code \\
\hline
\end{tabular}

\begin{tabular}{|c|c|c|c|c|c|c|}
\hline \multicolumn{7}{|c|}{ Examination Assessment } \\
\hline Scoring & $\begin{array}{l}\text { Pass/fail } \\
\text { (merit, } \\
\text { distinction) }\end{array}$ & $\begin{array}{l}\text { Validity, } \\
\text { reliability }\end{array}$ & $\begin{array}{l}\text { Standard (e.g. } \\
\text { Translation Quality } \\
\text { Assessment (TQA), } \\
\text { error } \\
\text { analysis/deduction } \\
\text { and/ or criterion- } \\
\text { referencing } \\
\text { (descriptor) }\end{array}$ & $\begin{array}{l}\text { Theoretical bases \& external } \\
\text { factors (e.g. client's needs) }\end{array}$ & $\begin{array}{l}\text { A reliable } \\
\text { translation }\end{array}$ & $\begin{array}{ll}\text { Amount } & \text { and } \\
\text { types of } & \text { test } \\
\text { items, } & \text { test } \\
\text { content, } & \\
\text { evaluation } & \\
\text { rubrics, } & \\
\text { transparency }\end{array}$ \\
\hline Length & $\begin{array}{l}\text { SEM } \\
\text { (Standardised } \\
\text { Error } \\
\text { Marking) }\end{array}$ & Correlation & Impact, washback & Practicality & Fairness & Screening tests \\
\hline Skills & Rendering & $\begin{array}{l}\text { Subject } \\
\text { area }\end{array}$ & Extralinguistic & $\begin{array}{l}\text { The whole competencies (e.g. } \\
\text { strategic, psychophysiological/ } \\
\text { attitudinal, etc.) }\end{array}$ & Degree & \\
\hline
\end{tabular}


Rater's Assessment: Reliability

TABLE XII.

A MOdEL OF CERTIFICATION PROGRAM FOR CERTIFIED INTERPRETERS

\begin{tabular}{|c|c|c|c|c|c|c|}
\hline \multicolumn{7}{|c|}{ Exam (Test/Task) } \\
\hline Level & $\begin{array}{l}\text { General/average } \\
\text { knowledge }\end{array}$ & \multirow[b]{2}{*}{$\begin{array}{l}\text { or/ } \\
\text { and }\end{array}$} & $\begin{array}{l}\text { Advanced knowledge, } \\
\text { professional knowledge }\end{array}$ & Paraprofessional & \multirow[b]{2}{*}{ or } & $\begin{array}{l}\text { Long term training (i.e. } \\
\text { obtaining postgraduate level) }\end{array}$ \\
\hline $\begin{array}{l}\text { Type of } \\
\text { Exam/ } \\
\text { Task }\end{array}$ & $\begin{array}{l}\text { Multiple choice, } \\
\text { written, oral } \\
\text { summary, } \\
\text { interpreting }\end{array}$ & & $\begin{array}{l}\text { Interview, listening, } \\
\text { interpreting, presentation, } \\
\text { simultaneous exercises }\end{array}$ & $\begin{array}{lr}\text { Simulated } & \text { situation/ } \\
\text { assessing } & \text { specific } \\
\text { performance } & \\
\text { skills/project/consecutive } \\
\text { and sight translation }\end{array}$ & & $\begin{array}{l}\text { Work experience (or an } \\
\text { equivalent/recommendations } \\
\text { from service-users) }\end{array}$ \\
\hline
\end{tabular}

\begin{tabular}{|c|c|c|c|c|c|c|c|}
\hline \multicolumn{8}{|c|}{ Proficiency (Candidate) } \\
\hline Level & $\begin{array}{l}\text { General } \\
\text { knowledge (e.g. } \\
\text { Aptitude Test) }\end{array}$ & $\begin{array}{l}\text { Source } \\
\text { Text (ST) } \\
\text { delivery }\end{array}$ & Fluency & $\begin{array}{l}\text { Target Language (TL) } \\
\text { quality (e.g. reliable } \\
\text { interpreting) }\end{array}$ & Interpreting skills & $\begin{array}{l}\text { Metacognitive } \\
\text { strategy }\end{array}$ & Culture \\
\hline
\end{tabular}

Rater's Proficiency: Training + (Calibration/Monitoring)/(No) Detailed Descriptions

\begin{tabular}{|c|c|c|c|c|c|c|c|c|c|}
\hline \multicolumn{10}{|l|}{ Assessment } \\
\hline \multirow[b]{2}{*}{ Candidate } & Pass mark & Validity & Accuracy & Fluency & $\begin{array}{l}\text { Education/ } \\
\text { degree }\end{array}$ & \multicolumn{2}{|c|}{ Performance skills } & \multicolumn{2}{|c|}{$\begin{array}{l}\text { Language } \\
\text { ability }\end{array}$} \\
\hline & Experience & $\begin{array}{l}\text { Professional } \\
\text { certification }\end{array}$ & Exam & Delivery & Proficiency & \multicolumn{4}{|c|}{ Pleasant voice } \\
\hline Examination & \multicolumn{2}{|l|}{ Fidelity } & Authenticity & Practicality & $\begin{array}{l}\text { Impact \& } \\
\text { washback }\end{array}$ & \multicolumn{4}{|c|}{$\begin{array}{l}\text { Validity, reliability, (practicality, } \\
\text { fairness, washback) }\end{array}$} \\
\hline Rater & Pass/fail & & Reliability & $\begin{array}{l}\text { Decision } \\
\text { consistency }\end{array}$ & $\begin{array}{l}\text { Intraclass } \\
\text { correlation }\end{array}$ & $\begin{array}{l}\text { Idiomaticity } \\
\& \\
\text { correctness }\end{array}$ & Tra & ing & Fidelity \\
\hline
\end{tabular}

\section{REFERENCES}

[1] ATA Website. (2019). ATA exam. Retrieved July 15, 2019, from www.atanet.org.

[2] CTTIC Website. (2011, 2019). Candidate guide. Retrieved July $15, \quad 2019$, from http://www.cttic.org/examDocs/CandidateGuide_En1011.pdf.

[3] CTTIC Website. (2019). Certification. Retrieved July 15, 2019, from http://www.cttic.org/certification.asp.

[4] The infoFinland Website. (2019). Do you need an interpreter? Retrieved July 15, 2019, from https://www.infofinland.fi/en/living-in-finland/as-an-immigrant-in-finland/do-you-need-an-interpreter.

[5] Research Division Office: National Center for State Courts. (2019). Court interpretation: Qualifications for court interpreting. Retrieved July 15, 2019, from http://cdm16501.contentdm.oclc.org/cdm/ref/collection/accessfair/id/95.

[6] Bachman, L. F. (1991). Fundamental considerations in language testing. Hong Kong: Oxford University Press.

[7] Bowker, L. (2005). Professional recognition in the Canadian translation industry: How is it perceived by translators and employers? In A. Darwish et. al. Translation Watch Quarterly, 1(1), 19-32. Australia: Translation Standards Institutes.

[8] Chen, J. (2009, 2014). Authenticity in accreditation tests for interpreters in China. The Interpreter and Translator Trainer, 3(2), 257-273. doi: 10.1080/1750399X.2009.10798791. Retrieved July 15, 2019, from http://dx.Doi.org/10.1080/1750399X.2009.10798791.

[9] Clifford, A. (2005). Putting the exam to the test: Psychometric validation and interpreter certification. Interpreting, 7 (1), $97-$ 131. doi: 10.1075/intp.7.1.06cli. Retrieved July 16, 2019, from https://www.researchgate.net/publication/228341742_Putting_the_exam_to_the_test_Psychometric_validation_and_interpreter certification.

[10] Fai,(n.d.). The development of an accreditation system for legal translators in Hong Kong (Master's Project). Retrieved July16, 2019, from www.hkilt.com/news/52_MA\%20project\%20(Vicor\%20Yu).pdf

[11] Gerver, D., Longley, P. E., Long, J., \& Lambert, S. (1989). Selection tests for trainee conference interpreters. Meta Journal, 34 (4), 724-735. doi: 10.7202/002884ar. Retrieved July 16, 2019, from https://www.researchgate.net/publication/271179894_Selection_Tests_for_Trainee_Conference_Interpreters

[12] Hall, J. (2011). Applying translation quality standards to a certification procedure for U.S. language service providers (Master's Thesis, University of Denver). Retrieved July 19, 2019, from http://www.jjhall.net/wp-content/uploads/2015/07/CapstoneProject_JasonHall_11.22.2011.pdf

[13] Han, Ch. (2015). Building the validity foundation for interpreter certification performance testing (Doctoral Dissertation, $\begin{array}{llllll}\text { Macquarie } & \text { University). } & \text { Retrieved } & \text { July } & \text { 19, } & \text { 2019, }\end{array}$ https://pdfs.semanticscholar.org/dd6c/5cf3266bb9e542f59560a56ef930384ee8fc.pdf

[14] Hlavac, J. (2013). A cross-national overview of translator and interpreter certification procedures. The International Journal of Translation \& Interpreting Research, 5(1), 32-65. doi: 10.12807/ti.105201.2013.a02. Retrieved July 15, 2019, from http://www.trans-int.org/index.php/transint/article/view/184

[15] Kafi, M., Khoshsaligheh, M., \& Hashemi, M. R. (2018). Translataion profession in Iran: Current challenges and future prospects. The Translator, 2(1), 89-103. doi: 10.1080/13556509.2017.1297693. Retrieved July 15, 2019, from https://Doi.org/10.1080/13556509.2017.1297693 
[16] Ko, L. (2005). NAATI accreditation for translators in Australia: Theoretical underpinnings and practical implications. In A. Darwish et. al, Translation Watch Quarterly 1 (1), 46-58. Australia: Translation Standards Institutes.

[17] Koby, G. S., \& Baer, B. J. (2005). From professional certification to the translator training classroom: Adapting the ATA error marking scale. In A. Darwish et. al. Translation Watch Quarterly, 1(1), 33-45. Australia: Translation Standards Institutes.

[18] Koby, G. S., \& Melby, A. K. (2013). Certification and job task analysis (JTA): Establishing validity of translator certification examinations. The International Journal for Translation \& Interpreting Research, 5 (1), 174-210. doi: ti.105201.2013.a10

[19] Lee, J. (2008, 2014). Rating scales for interpreting performance assessment. The Interpreter and Translator Trainer, 2(2), 165184. doi: 10.1080/1750399X.2008.10798772.

[20] Liu, M. H. (2013). Design and analysis of Taiwan's interpretation certification examination. In D. Tsagari \& R. van Deemter (Eds.), Assessment issues in language translation and interpreting (pp. 163-178). Frankfurt am Main: Peter Lang.

[21] Skyba, K. (2014). Translators and interpreters certification in Australia, Canada, the USA and Ukraine: Comparative analysis. Comparative Professional Pedagoagy, 4 (3), 58-64. doi: 10.2478/rpp-2014-0036.

[22] Turner, B., Lai, M., \& Huang, N. (2010). Error deduction and descriptors: A comparison of two methods of translation test assessment. The International Journal for Translation \& Interpreting Research, 2 (1), 11-23. Retrieved July 15, 2019, from http://www.trans-int.org/index.php/transint/article/view/42/66

[23] Wallace, M. (2013). Rethinking bifurcated testing models in the court interpreter certification process. In D. Tsagari \& R. van Deemer (Eds.), Language testing and evaluation: Assessment issues in language translation and interpreting, $29,67-81$. Frankfurt: Peter Lang Edition.

[24] Wong, J. TC. (n.d.). A comparative study on the credentialing (certification) of legal translators. Johnson Journal, 1-23. Retrieved July 15, 2019, from http://www.hkilt.com/news/60_Johnson\%20Journal.pdf

[25] Zhao, H., \& Gu, X. (2016). China accreditation test for translators and interpreters (CATTI): Test review based on the language pairing of English and Chinese. Language Testing, 33 (3), 439-446. doi: 10.1177/0265532216643630.

[26] Zou, M., \& Wu, W. (2015). Review on China accreditation test for translators and interpreters (CATTI). English Language Teaching, 8 (7), 152-156. doi:10.5539/elt.v8n7p152.

Yaghoob Javadi is an assistant professor of Applied Linguistics teaching postgraduate courses including Second Language Acquisition Studies, Curriculum Planning, Computer Enhanced Language Learning, and Language, Culture and Identity. His current research interests include cultural and cognitive aspects of second language acquisition, identity, CALL, curriculum planning and teacher education.

Tahereh Khezrab is a PhD candidate in TEFL. She completed her studies in Translation Studies for B.A. and M.A. degrees. Her current research interests constitute teaching translation, legal and business translation and interpreting. 